Sains Malaysiana 49(3)(2020): 573-581

http://dx.doi.org/10.17576/jsm-2020-4903-12

\title{
Crystalline Silica Exposure and Air Quality Perception of Residents Living Around Home Stone Factories
}

(Dedahan Habluran Silika dan Persepsi Kualiti Udara Penduduk yang Tinggal di Sekitar Kilang Batu Rumah)

\author{
Sakesun Thongtip, Penprapa Siviroj*, Athavudh DeesomchoK, AnaWat Wisetborisut \& \\ TIPPAWAN PRAPAMONTOL
}

\begin{abstract}
Stone factories containing harmful inhalable crystalline silica that can penetrate deep into the respiratory system causing silicosis. People living around stone factories should be concerned about the risk of dust pollutants. This study aimed to assess the crystalline silica concentrations and air quality perception (AQP) among residents living around home stone factories. Forty samples of $P M_{10}$ and crystalline silica concentrations were collected from 11 home stone factories and measured following the NIOSH methods 0600 and 7601. A cross- sectional study was carried out into 325 subjects who were interviewed using the AQP and respiratory symptoms questionnaires, and a Geographic Information System technique for distance from stone factories was measured. The average crystalline silica concentrations of all stone factories were higher than the recommendation. Bivariate analyses showed that the subjects' age, income, occupation, smoking, distances, and number of respiratory symptoms were associated with AQP. Interestingly, those with distance from stone factories lower than $50 \mathrm{~m}$ had a poorer AQP than those whose distance from stone factories was more than $100 \mathrm{~m}$ (cOR 2.5, 95\%CI: 1.3-4.9). An increasing number of respiratory symptoms was associated with a poor quality of air perception $(B=0.752, S E=0.242)$ and those which had chest pain, nose irritation and stuffy nose were associated with a poor AQP. All home stone factories produce inhalable dust pollutants. The AQP can be used to link distances from pollutant sources and have a relationship with respiratory symptoms. Periodically monitor dust pollutants exposure, AQP and surveillance of respiratory illness should be done.
\end{abstract}

Keywords: Air quality perception; crystalline silica; GIS; home stone factory; respiratory symptoms

\section{ABSTRACT}

Kilang batu mengandungi habluran silika sedutan berbahaya yang boleh menembusi jauh ke dalam sistem pernafasan dan menyebabkan silikosis. Penduduk yang tinggal di sekitar kawasan kilang batu seharusnya bimbang tentang risiko pencemaran debu. Kajian ini bertujuan menilai kepekatan habluran silika dan persepsi kualiti udara (AQP) dalam kalangan penduduk yang tinggal di sekitar kawasan kilang batu rumah. Empat puluh sampel PM ${ }_{10}$ dan kepekatan habluran silika dikumpul daripada 11 kilang batu rumah dan diukur menggunakan kaedah NIOSH 0600 dan 7601. Suatu kajian rentas telah dijalankan ke atas 325 subjek yang ditemu bual menggunakan AQP dan soal selidik gejala pernafasan serta teknik Sistem Maklumat Geografi digunakan untuk mengukur jarak daripada kilang batu. Purata kepekatan habluran silika kesemua kilang batu adalah lebih tinggi daripada yang disarankan. Analisis bivariat menunjukkan umur, pendapatan, pekerjaan, perokok, jarak serta gejala pernafasan subjek dikaitkan dengan AQP. Menariknya, subjek dengan jarak daripada kilang batu kurang daripada $50 \mathrm{~m}$ mempunyai AQP yang lebih rendah berbanding subjek dengan jarak $100 \mathrm{~m}$ daripada kilang batu (cOR 2.5, 95\% CI: 1.3-4.9). Peningkatan gejala pernafasan dikaitkan dengan persepsi kualiti udara yang kurang baik $(B=0.752, S E=0.242)$ dan subjek yang mengalami sakit dada, gatal hidung serta hidung tersumbat dikaitkan dengan AQP yang rendah. Semua kilang batu rumah menghasilkan pencemaran debu sedutan. AQP boleh digunakan untuk menghubungkan jarak daripada sumber pencemaran dan mempunyai perkaitan dengan gejala pernafasan. Kawalan secara berkala dedahan pencemaran debu, AQP dan pengawasan penyakit pernafasan sepatutnya dijalankan.

Kata kunci: Gejala pernafasan; GIS; habluran silika; kilang batu rumah; persepsi kualiti udara

\section{INTRODUCTION}

Air pollution is a growing global environmental problem especially from the increasing presence and concentration of inhalable particulate matters $\left(\mathrm{PM}_{\mathrm{S}}\right)$. Inhalable PM with diameters less than ten micrometers or $\mathrm{PM}_{10}$ are complex mixtures of small solid and liquid particles suspended in the air and which can affect human health and ecosystems both in the short and long term (Cassee et al. 2013; Deguen et al. 2015). Reportedly, in 2012 seven million premature deaths worldwide were caused and $\mathrm{PM}_{10}$ was responsible for $30 \%$ of the cases of ischemic heart disease and strokes, $17 \%$ of the deaths related to chronic obstructive pulmonary 
diseases or acute lower respiratory infections, and $9 \%$ of the deaths from lung cancer (Mannucci \& Franchinni 2017).

Most particles of air pollution are the result of complex interactions of chemicals which are emitted from both natural and anthropogenic sources. However, the current air pollution is largely attributable to human activity. Heavy industries emit pollutants to the air causing health problems for both occupational workers and people living near the sources (Cassee et al. 2013; Deguen et al. 2015; Liao et al. 2015; Mannucci \& Franchinni 2017). Particularly, PM $_{10}$ originates from activities related to construction, glass products, pottery products, construction stone, masonry and stone products invariably containing respirable crystalline silica (Healy et al. 2014; Scarselli et al. 2011).

Home stone production has been an informal laborintensive cottage industry for years and it renders an occupational exposure to human health risks. This is because dust or very fine particles from stone operation contain harmful inhalable crystalline silica which can penetrate deep into the respiratory system and cause such occupational lung disease as silicosis (Ibhafidon et al. 2014; Mukhopadhyay et al. 2011; Rafeemanesh et al. 2014). In 1997, the International Agency for Research on Cancer (IARC) classified crystalline silica as a Group 1 human carcinogen (Vacek et al. 2011). Frequent or prolonged exposure to crystalline silica often occurs as part of working in or living near the home stone factories but many exposed persons may not be aware of the potential health hazards from working and living in their familiar environment (Charles et al. 2013; Omanga et al. 2014; Shi \& He 2012).

As a result, it is imperative to determine whether people living in the neighborhood of stone factories have air quality perception as well as health risk awareness. The lack of awareness or the low level of perception means a lower likelihood for the individual to behave in selfprotective ways to avoid the harm from air pollution (Liao et al. 2015; Qian et al. 2016). The perceived level of air pollution in occupational or living environments can effect a change toward self-protective behaviors to minimize health risks (Egondi et al. 2013; Haas et al. 2016). Empirically, it has been found that air quality perception varies positively with health risk perception and that low levels of air quality perception results in low levels of self-protective pursuits. In other words, people having a higher level of awareness regarding health risks from air pollution tend to have stronger self-protective behaviors than those having a lower level of awareness (Crowe 1968; Deguen et al. 2012; Guo et al. 2016; Shi \& He 2012).

As perception can be influenced by the distance from pollution sources, this spatial dimension became a focal point in this study. Although by nature and from various reports ambient air pollutant concentrations will be high at and around the point source of pollution, the air pollutants can be dispersed to more remote communities at higher concentrations and thus can pose health risks to the residents there (Madungwe \& Mukonzvi 2012). To tackle this issue, many research studies have applied the geographic information system (GIS) technique for mapping the spatial dispersion and concentrations of air pollutants generated from a point source, or for studying the relationship between distance and air quality or the health risk perceptions of residents in an affected area. However, from a literature review, meager studies and research have been undertaken related to the implications of stone production as it is generally an informal cottage industry in various developing countries where appropriate occupational and environmental health protective measures are still lacking (Brody et al. 2004; Piro et al. 2008; Severtson \& Burt 2012). Therefore, we aimed to assess the $\mathrm{PM}_{10}$ and crystalline silica concentrations and air quality perception among residents living around the home stone factories.

\section{MATERIALS AND METHODS}

\section{STUDY DESIGN, POPULATION AND SAMPLING}

This study was a cross-sectional study. We collected dust pollutants from 11 home stone factories currently in operation. A simple random sampling method was used, and sample size was calculated for estimating the proportion of a finite population. We selected 325 subjects (37.5\%) of a total population of 866 people. The inclusion criteria of this study were subjects who were at least 18 years old and above, had lived in this community for at least one year, and were not currently stone workers. The exclusion criteria were those unable to verbally communicate in the Thai language, had been diagnosed with mental disorders or affective disorders. The formula for sample size calculation based on the proportion of air pollution risk perception was eligible further analysis at 48\% (Omanga et al. 2014). The n4Studies was used for sample size calculation (Ngamjarus 2016) as (1):

$$
n=\frac{N p(1-p) z_{1-\frac{\alpha}{2}}^{2}}{d^{2}(N-1)+p(1-p) z_{1-\frac{\alpha}{2}}^{2}}
$$

where $\mathrm{N}$ is 866 ; $\mathrm{p}$ is 0.48 ; Delta is 0.048 ; Alpha is $0.05, \mathrm{Z}$ $(0.975)$ is 1.960 ; and $n$ (sample size) is 282 .

We added at least $15 \%$ to the estimated sample size to allow for losses. Therefore, the sample size needed to be 325 subjects.

\section{DATA COLLECTION AND MEASUREMENT}

Forty-one personal samplers measured $\mathrm{PM}_{10}$ and silica concentration in 11 stone factories. The participants were recruited into the study after review and approval of the informed consent which was signed before collecting the data. All subjects were interviewed including demographic data (age, sex, education, marital status, income, occupation, and the time living in this community), medical history (co-morbidities), lifestyle habits (current smoker 
and alcohol user), respiratory symptoms, and air quality perception. Dust pollutant exposure levels and a Geographic Information System (GIS) technique for distance from home to stone factories were measured.

Dust pollutant exposure levels Personal concentrations of particulate matter $\left(\mathrm{PM}_{10}\right)$ were assessed using personal sampling and following the National Institute for Safety and Health guidelines; the NIOSH method 0600 (NIOSH 1998) and 7601 (Silica, Crystalline, by VIS) and 7601 (NIOSH 2003). All samples were collected using cyclones, (Respirable Dust Nylon Cyclone, SKC, UK) at a flow of $1.7 \mathrm{~L} / \mathrm{min}$ calibrated by using a soap bubble meter. Polyvinyl chloride (PVC) filters $(37 \mathrm{~mm}$ polystyrene cassette with a $5 \mu \mathrm{m}$ pore size) were used for all sampling. The cyclone sampler vests were hung in the workers' breathing zone. The PVC filter were weighed before and after sampling to analyze the concentration of $\mathrm{PM}_{10}$ before it was evaluated for silica by visible absorption spectrophotometry.

Distance from home to stone factories A Garmin eTrex $30 \times$ GPS tool was used to measure the distance between residential homes and stone factories which was the air pollution source. After that, we calculated the minimum distance from home to the nearest stone factory. The obtained geospatial data were processed into map form using direct measurement by the Quantum Geographic Information System (QGIS) software.

Respiratory symptoms The respiratory symptoms questionnaire used in the interviews included respiratory symptoms such as coughing, phlegm, coughing with phlegm, wheezing, difficulty in breathing, chest pain, nose irritation and stuffy nose following the standardized American Thoracic Society Division of Lung Disease Questionnaire (ATS-DLD-78A) (Helsing et al. 1979). We used the ATS-DLD-78A questionnaire, Thai version that was tested for validity and reliability by Doungrutai (1999).

Air quality perception AQP was measured using an AQP scale originally used in France which was translated into the Thai language with the contents synthesized from the forward and backward translations with content validity. The original air quality perception scale was tested for validity and reliability by Deguen et al. (2012). In addition, we tested the reliability of the AQP questionnaire, Thai version, and the alpha coefficient of this AQP questionnaire was 0.801 . It contains 22 items with four subscales (never, occasionally, often, and always perceived) to assess risk perception (anxiety about health and quality of life) and the extent to which air pollution is a nuisance (sensorial perception and symptoms). Scores of at least 22 indicated a poor air pollution perception or a high level of risk perception while the scores lower than 22 indicated a good air quality perception or a low level of risk perception (Deguen et al. 2012, 2008).

\section{STATISTICAL ANALYSIS}

Descriptive statistics; frequencies, means, standard deviations, were used to describe the sample. The relationship between demographics, health characteristics, distance from home to stone factories and AQP was analyzed by binary logistic regression. The association between respiratory symptoms and AQP was analyzed by multiple logistic regression. Additionally, factors associated with AQP were analyzed by multiple linear regression. Statistical significance was taken as a $p$-value $<0.05$.

\section{ETHICAL CONSIDERATIONS}

The study was approved by the Research Ethics Committee of the Faculty of Medicine, Chiang Mai University, Thailand (No. 243/2016).

\section{RESULTS}

\section{SAMPLE CHARACTERISTICS AND COMMUNITY LOCATION}

This study was conducted in two villages in Ban Sang Sub-District, Phayao Province, Thailand (UTM zone 47Q east: 0587424 north: 2119035) (Figure 1(A)) where 11 home stone factories are operating using the Google Earth Program (Figure 1(B)). Among the participants, 155 $(47.7 \%)$ were males and $170(52.3 \%)$ females; with the average age of 56.1 years old.

\section{$\mathrm{PM}_{10}$ AND CRYSTALLINE SILICA CONCENTRATIONS}

The average concentration of $\mathrm{PM}_{10}$ in all factories was lower than NIOSH and the American Conference of Government Industrial Hygienist (ACGIH), while the crystalline silica concentration in all factories were higher than NIOSH and ACGIH allowed extent $\left(0.025 \mathrm{mg} / \mathrm{m}^{3}\right)$ (Table 1).

The concentration of $\mathrm{PM}_{10}$ and crystalline silica were significantly correlated by using linear regressions (Figure $2)$. The linear relationships for each concentration of the variability in the data, as determined by the $R^{2}$-value of the regressions (where y is the silica concentration $\left(\mathrm{mg} / \mathrm{m}^{3}\right.$ ) and $\mathrm{x}$ is the $\mathrm{PM}_{10}$ concentration $\left(\mathrm{mg} / \mathrm{m}^{3}\right)$ ).

\section{FACTORS ASSOCIATED WITH AIR QUALITY PERCEPTION}

Seventy-nine participants $(24.3 \%)$ were found to have a poor air quality perception or high-risk perception. Demographic and health characteristics associated with the AQP level were presented in Table 2. Subjects' ages between 46 and 59 years and below 45 years had a poorer AQP than ages over 60 years (cOR 2.2, $95 \%$ CI: 1.2-4.0; cOR $2.2,95 \%$ CI: 1.1-4.7, respectively). Subjects with incomes at 1,001-4,000 baht/month $(\sim 31.3-125.0$ US dollars) and $>4,001$ baht/month ( 125.0 US dollars) had a poorer AQP than subjects with incomes at $\leq 1,000 \mathrm{baht} /$ month ( 31.3 US dollars) (cOR 3.4, $95 \%$ CI: 1.7-6.8; cOR $3.6,95 \%$ CI: 1.8-7.1, respectively). Subjects with moderate 


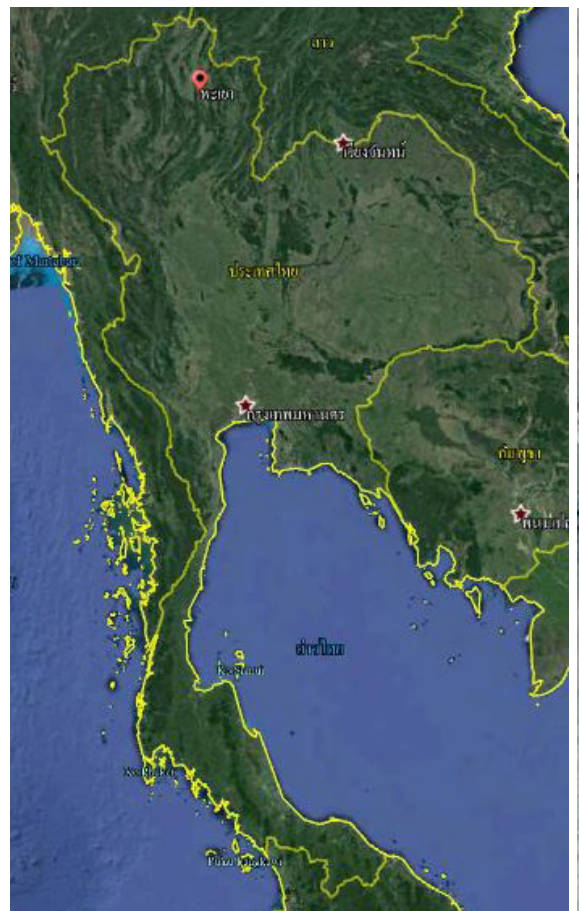

(A)

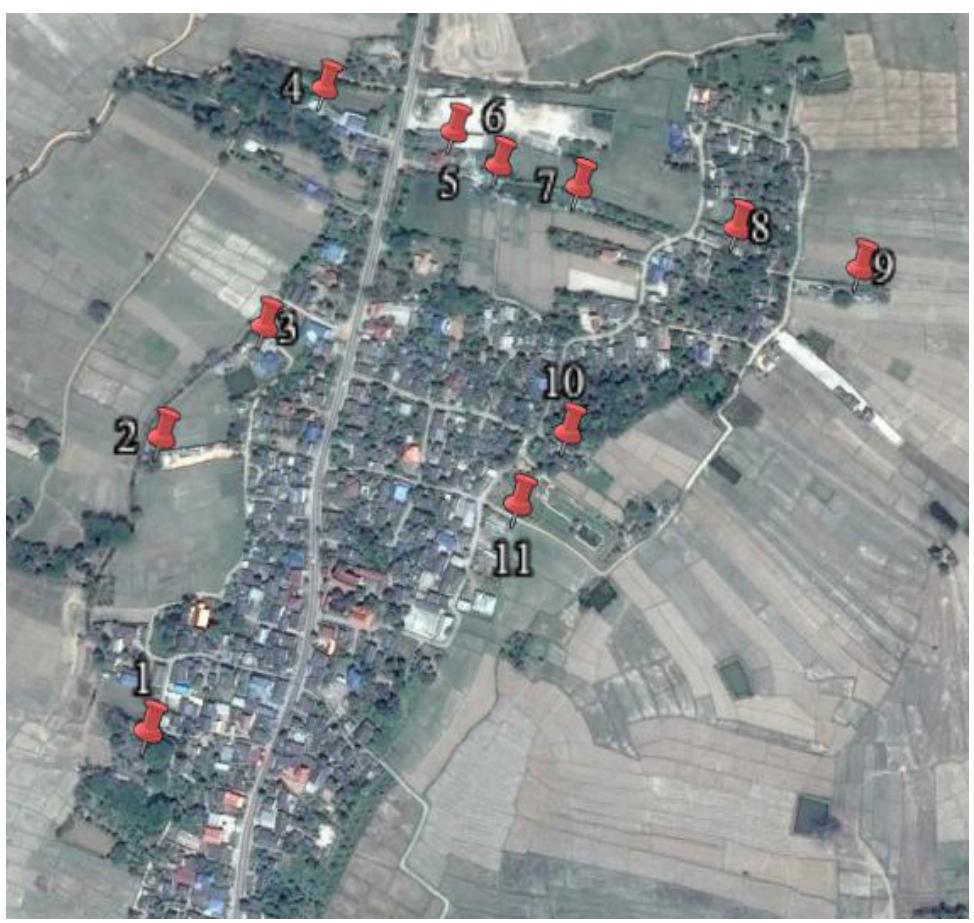

(B)

FIGURE 1. (A) Location map of study area in Phayao Province, Thailand using the Google Earth Program (B) Location map of 11 home stone factories in the study area; $\$=$ stone factory using the Google Earth Program

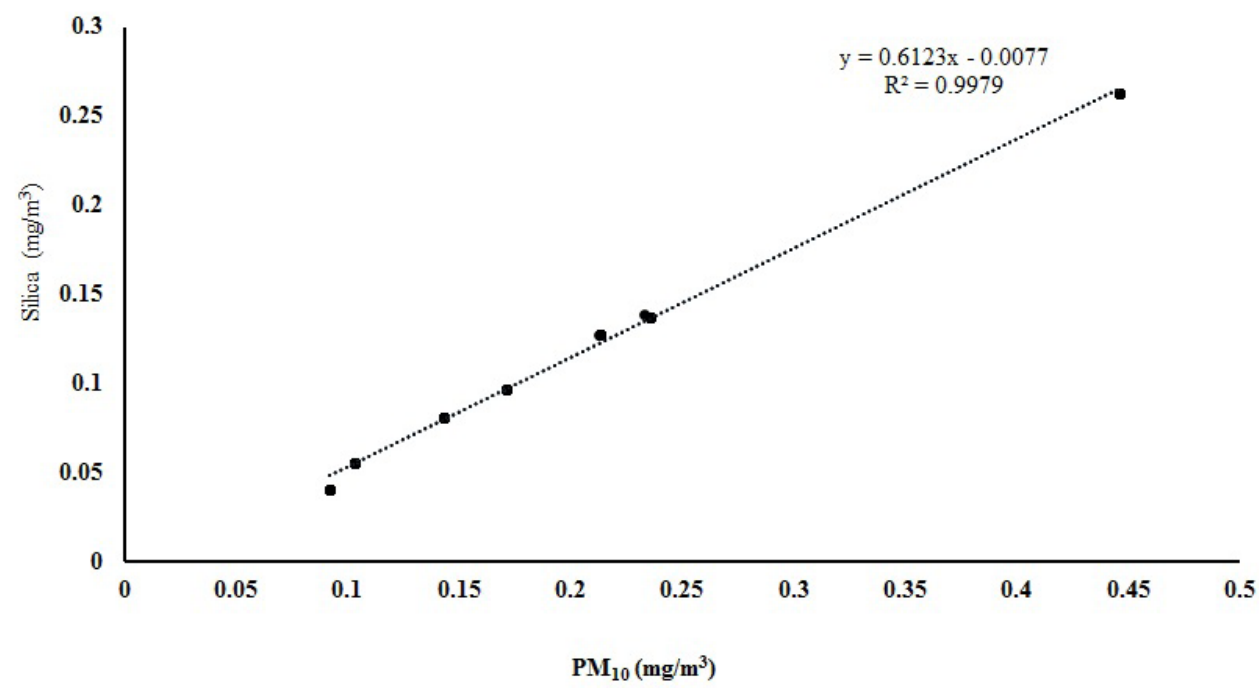

FIGURE 2. Relationship between $\mathrm{PM}_{10}$ and crystalline silica concentrations of home stone factories

labor and heavy labor had a poorer AQP than light labor (cOR 2.9, 95 \% CI: 1.4-6.1; cOR 2.8, 95 \% CI: 1.3-6.2, respectively). Subjects who were smokers had a poorer AQP than non-smokers (cOR 3.0, $95 \%$ CI: 1.6-5.3). Subjects who had more than three respiratory symptoms had a poorer AQP than those with no symptoms (cOR 2.9, $95 \%$ CI: 1.6-5.0). Interestingly, those with distance from home to stone factories between 51 and 100 meters and lower than 50 meters had a poorer AQP than those whose distance from home to stone factories more than 100 meters
(cOR 1.8, 95 \% CI: 1.1-3.0; cOR 2.5, 95 \% CI: 1.3-4.9, respectively).

ASSOCIATION BETWEEN RESPIRATORY SYMPTOMS AND AIR QUALITY PERCEPTION

The most common respiratory symptoms were cough $(22.2$ $\%$ ), phlegm (14.2\%), nose irritation (13.8\%), stuffy nose $(12.3 \%)$, cough with phlegm $(11.7 \%)$, and chest pain $(10.8 \%)$. The association between respiratory symptoms and AQP was presented in Table 3. Subjects with difficulty 
TABLE 1. $\mathrm{PM}_{10}$ and crystalline silica concentrations in 11 home stone factories

\begin{tabular}{lcccc}
\hline Stone factories $(\mathrm{na}=41)$ & \multicolumn{2}{c}{$\mathrm{PM}_{10}$ concentration $(\mathrm{mg} / \mathrm{m} 3)$} & \multicolumn{2}{c}{ Crystalline silica concentration $(\mathrm{mg} / \mathrm{m} 3)$} \\
& Mean $\pm \mathrm{SD}$ & Min - Max & Mean $\pm \mathrm{SD}$ & Min - Max \\
\hline Factory $1(\mathrm{na}=4)$ & $0.236 \pm 0.102$ & $0.110-0.360$ & $0.137 \pm 0.050^{*}$ & $0.072-0.194$ \\
Factory 2 $(\mathrm{na}=4)$ & $0.092 \pm 0.033$ & $0.045-0.120$ & $0.040 \pm 0.039^{*}$ & $0.005-0.075$ \\
Factory 3 $(\mathrm{na}=2)$ & $0.446 \pm 0.289$ & $0.242-0.650$ & $0.263 \pm 0.182^{*}$ & $0.134-0.391$ \\
Factory 4 $(\mathrm{na}=6)$ & $0.233 \pm 0.131$ & $0.136-0.491$ & $0.139 \pm 0.095^{*}$ & $0.053-0.316$ \\
Factory 5 $(\mathrm{na}=6)$ & $0.902 \pm 1.079$ & $0.048-2.706$ & $0.169 \pm 0.163^{*}$ & $0.027-0.453$ \\
Factory 6 $(\mathrm{na}=2)$ & $0.673 \pm 0.845$ & $0.075-1.270$ & $0.150 \pm 0.150^{*}$ & $0.044-0.256$ \\
Factory 7 $(\mathrm{na}=3)$ & $0.171 \pm 0.049$ & $0.122-0.220$ & $0.097 \pm 0.039^{*}$ & $0.055-0.131$ \\
Factory $8(\mathrm{na}=2)$ & $0.213 \pm 0.045$ & $0.181-0.244$ & $0.127 \pm 0.031^{*}$ & $0.105-0.149$ \\
Factory 9 $(\mathrm{na}=5)$ & $0.287 \pm 0.142$ & $0.114-0.503$ & $0.170 \pm 0.090^{*}$ & $0.060-0.309$ \\
Factory 10 $(\mathrm{na}=4)$ & $0.143 \pm 0.075$ & $0.050-0.234$ & $0.081 \pm 0.052^{*}$ & $0.024-0.151$ \\
Factory 11 $(\mathrm{na}=3)$ & $0.103 \pm 0.056$ & $0.058-0.166$ & $0.055 \pm 0.041^{*}$ & $0.030-0.103$ \\
\hline
\end{tabular}

$\mathrm{n}^{\mathrm{a}}=$ number of personnel dust samplers for each factory; *Higher than the standard level of ACGIH; Silica $\left(0.025 \mathrm{mg} / \mathrm{m}^{3}\right)$ at eight-hour TWA

TABLE 2. Binary logistic regression analysis of the relationship between demographic and health characteristics, distance from home to stone factories and $\mathrm{AQP}$

\begin{tabular}{|c|c|c|c|c|}
\hline \multirow[t]{2}{*}{ Variables } & \multirow[t]{2}{*}{ N (\%) } & \multicolumn{2}{|c|}{$\mathrm{AQP}$} & \multirow[t]{2}{*}{$\operatorname{cOR}(95 \% \mathrm{CI})$} \\
\hline & & $<22$ Scores $246(75.7)$ & $\geq 22$ Scores $79(24.3)$ & \\
\hline \multicolumn{5}{|l|}{$\operatorname{Sex}^{\mathrm{a}}$} \\
\hline Female & $170(52.3)$ & $133(54.1)$ & $37(46.8)$ & Ref. \\
\hline Male & $155(47.7)$ & $113(45.9)$ & $42(53.2)$ & $1.3(0.8-2.2)$ \\
\hline $\mathrm{Age}^{\mathrm{b}}$ (years), mean $\pm \mathrm{SD}$ & $56 \pm 15.3$ & & & \\
\hline$\geq 60$ & $125(38.5)$ & $105(42.7)$ & $20(25.3)$ & Ref. \\
\hline $46-59$ & $141(43.4)$ & $100(40.7)$ & $41(51.9)$ & $2.2(1.2-4.0)^{*}$ \\
\hline$\leq 45$ & $59(18.2)$ & $41(16.7)$ & $18(22.8)$ & $2.2(1.1-4.7)^{*}$ \\
\hline \multicolumn{5}{|l|}{ Income (baht/month) ${ }^{\mathrm{b}}$} \\
\hline mean $\pm \mathrm{SD}$ & $4154.2 \pm 5974.9$ & & & \\
\hline$\leq 1,000$ & $126(38.8)$ & $111(45.1)$ & $15(19.0)$ & Ref. \\
\hline $1,001-4,000$ & $95(29.2)$ & $65(26.4)$ & $30(38.0)$ & $3.4(1.7-6.8)^{* *}$ \\
\hline$\geq 4,001$ & $104(32.0)$ & $70(28.5)$ & $34(43.0)$ & $3.6(1.8-7.1)^{* *}$ \\
\hline \multicolumn{5}{|l|}{ Education $^{\mathrm{a}}$} \\
\hline$\leq$ Primary school & $240(73.8)$ & $182(74.0)$ & $58(73.4)$ & Ref. \\
\hline$>$ Primary school & $85(26.2)$ & $64(26.0)$ & $21(26.6)$ & $1.0(0.6-1.8)$ \\
\hline \multicolumn{5}{|l|}{ Marital Status ${ }^{\mathrm{a}}$} \\
\hline Single & $50(15.4)$ & $38(15.4)$ & $12(15.2)$ & Ref. \\
\hline Married & $275(84.6)$ & $208(84.6)$ & $67(84.8)$ & $1.0(0.5-2.1)$ \\
\hline \multicolumn{5}{|l|}{ Occupation $^{\mathrm{b}}$} \\
\hline Light labor & $82(25.2)$ & $72(29.3)$ & $10(12.7)$ & Ref. \\
\hline Moderate labor & $150(46.2)$ & $107(43.5)$ & $43(54.4)$ & $2.9(1.4-6.1)^{* *}$ \\
\hline Heavy labor & $93(28.6)$ & $67(27.2)$ & $26(32.9)$ & $2.8(1.3-6.2)^{*}$ \\
\hline \multicolumn{5}{|c|}{ Time of living in this community (years) } \\
\hline$<21$ & $19(5.8)$ & $13(5.3)$ & $6(7.6)$ & Ref. \\
\hline $21-40$ & $57(17.5)$ & $44(17.9)$ & $13(16.5)$ & $0.6(0.2-2.0$ \\
\hline$>40$ & $249(76.6)$ & $189(76.8)$ & $60(75.9)$ & $0.7(0.3-1.9)$ \\
\hline \multicolumn{5}{|l|}{ Smokinga } \\
\hline No & $264(81.2)$ & $211(85.8)$ & $53(67.1)$ & Ref. \\
\hline Yes & $61(18.8)$ & $35(14.2)$ & $26(32.9)$ & $3.0(1.6-5.3)^{* *}$ \\
\hline \multicolumn{5}{|l|}{ Alcohol use ${ }^{\mathrm{a}}$} \\
\hline No & $238(73.2)$ & $185(75.2)$ & $53(67.1)$ & Ref. \\
\hline Yes & $87(26.8)$ & $61(24.8)$ & $26(32.9)$ & $1.5(0.9-2.6)$ \\
\hline
\end{tabular}




\begin{tabular}{|c|c|c|c|c|}
\hline \multicolumn{5}{|c|}{ Respiratory symptoms (number) ${ }^{b}$} \\
\hline None & $210(64.6)$ & $171(69.5)$ & 39 (49.4) & Ref. \\
\hline $1-2$ & $34(10.5)$ & $26(10.6)$ & $8(10.1)$ & $1.4(0.6-3.2)$ \\
\hline$\geq 3$ & $81(24.9)$ & $49(19.9)$ & $32(40.5)$ & $2.9(1.6-5.0)^{* *}$ \\
\hline \multicolumn{5}{|c|}{$\begin{array}{l}\text { Co-morbidities } \\
\text { (number) }^{\mathrm{b}}\end{array}$} \\
\hline None & $233(71.7)$ & $182(74.0)$ & $51(64.6)$ & Ref. \\
\hline 1 & $82(25.2)$ & $59(24.0)$ & $23(29.1)$ & $1.4(0.8-2.5)$ \\
\hline$\geq 2$ & $10(3.1)$ & $5(2.0)$ & $5(6.3)$ & $3.6(1.0-12.8)$ \\
\hline \multicolumn{5}{|c|}{ Distance (meters) } \\
\hline$>100$ & $48(14.8)$ & $29(11.8)$ & $19(24.0)$ & Ref. \\
\hline $51-100$ & $109(33.5)$ & $79(32.1)$ & $30(38.0)$ & $1.8(1.1-3.0)^{*}$ \\
\hline$\leq 50$ & $168(51.7)$ & $138(56.1)$ & $30(38.0)$ & $2.5(1.3-4.9)^{* *}$ \\
\hline
\end{tabular}

$\mathrm{cOR}=$ crude odds ratio; $\mathrm{CI}=$ Confidence interval; ${ }^{*} p<0.05 ; * *<0.01 ; \mathrm{AQP}<22$ score $=$ a good $\mathrm{APQ}, \mathrm{AQP} \geq 22$ scores $=$ a poor $\mathrm{AQP}$

in breathing had a poorer AQP than non-difficulty in breathing (Crude Odd Ratio $=\mathrm{cOR} 2.9,95 \% \mathrm{CI}: 1.2-7.2$ ). Subjects with chest pain had a poorer AQP than non-chest pain (cOR 2.5, $95 \%$ CI: 1.2-5.0). Subjects with nose irritation had a poorer AQP than non-nose irritation (cOR 2.4, $95 \%$ CI: 1.3-4.5). Subjects with stuffy nose had a poorer AQP than non-stuffy nose (cOR 2.0, $95 \%$ CI: 1.0 3.9). However, chest pain, nose irritation and stuffy nose were also associated with a poorer AQP in the multivariable analysis after adjusting for age, income, occupation, smoking, and distance from home to stone factories (Table 3).

The multivariable analysis showed that an increased number of respiratory symptoms was associated with a poor AQP after adjusting for age, income, occupation, smoking and distance from home to stone factories. In addition, there were found that a high income level, current smoker, and a short distance from home to stone factories were associated with a poor AQP (Table 4).

\section{DISCUSSION}

Our studies found that the crystalline silica concentration in all factories were higher than the NIOSH and ACGIH standards for each stone process, such as stone cutting and grinding, in home stone factories. In addition, stone factories are a household products industry and mostly informal sector workers in which the study areas were an open system causing ventilation problems and lack appropriate air pollution controls. These results are consistent with the findings from previous research indicating high concentrations of crystalline silica in stone factories when compared with other occupational groups (Bhagia 2012). Moreover, other research found that the association between the high levels of respirable dust and crystalline silica concentrations (Kuo et al. 2018) are also consistent with the findings from our studies.

This studies found that the demographic characteristics can affect a poor AQP including age (young had poorer AQP than older), income (low income had poorer AQP than high income), occupation (moderate and heavy labors had poorer AQP than light labor), smoking (smokers had poorer AQP than non-smoker) and number of respiratory symptoms (increased the number of respiratory symptoms had poorer AQP). These results are consistent with the findings from previous research that the demographic characteristics and factors associated with AQP. In addition, those characteristics have bearings on air quality perception because of the context and personal traits can influence a person's perception of health risks from air pollution (Egondi et al. 2013; Guo et al. 2016; Omanga et al. 2014).

Our study found an increased number of respiratory symptoms was associated with a poor air quality perception. Especially, respiratory symptoms such as chest pain, nose irritation and stuffy nose had associated with a poor AQP. These results are consistent with the findings from previous research that those residents living close to home stone factories had more respiratory symptoms than those living far from the pollution sources (Brender et al. 2011). Especially a previous study showed Thai stone workers had high rate of respiratory symptoms (42-9-55.2 $\%)$ (Thongtip et al. 2019). In addition, these results showed that the health risk perceived level of air pollution significantly influences symptoms (Orru et al. 2018), they found that an increased number of respiratory symptoms, high income, high current smoker and low distance from home to stone factories were associated with a poor AQP. These results are consistent with the findings from previous research that the demographic characteristics and factors associated with AQP. Those characteristics have a bearing on air quality perception because the context and personal traits can influence a person's perception of health risks from air pollution (Egondi et al. 2013; Guo et al. 2016; Omanga et al. 2014).

Furthermore, the present research found that increasing distance from home to stone factories was associated with a good AQP. These studies showed that those residents living close to home stone factories had a poorer air quality perception than those living far from the pollution sources. This result is in agreement with the findings of other research studies that people living near 
TABLE 3. Association between respiratory symptoms and AQP using multiple logistic regression analysis

\begin{tabular}{lccccc}
\hline Symptoms & N $(\%)$ & \multicolumn{2}{c}{ Crude odd ratio } & \multicolumn{2}{c}{ Adjusted odd ratio } \\
& & OR & $95 \%$ CI & OR & $95 \%$ CI \\
\hline Coughing & $72(22.2)$ & 1.5 & $0.9-2.5$ & 1.4 & $0.7-2.6$ \\
Phlegm & $46(14.2)$ & 1.8 & $1.0-3.4$ & 2.0 & $1.0-4.3$ \\
Coughing with phlegm & $38(11.7)$ & 1.8 & $0.9-3.5$ & 1.5 & $0.7-3.4$ \\
Wheezing & $23(7.1)$ & 2.3 & $1.0-5.4$ & 1.8 & $0.7-4.7$ \\
Difficulty in breathing & $21(6.5)$ & 2.9 & $1.2-7.2^{*}$ & 1.4 & $0.5-4.0$ \\
Chest pain & $35(10.8)$ & 2.5 & $1.2-5.0^{*}$ & 3.6 & $1.6-8.0^{* *}$ \\
Nose irritation & $45(13.8)$ & 2.4 & $1.3-4.5^{* *}$ & 2.4 & $1.1-4.9^{*}$ \\
Stuffy nose & $40(12.3)$ & 2.0 & $1.0-3.9^{*}$ & 2.4 & $1.1-5.1^{*}$ \\
\hline
\end{tabular}

Adjusted by age, income, occupation, smoking, and distance from home to stone factories; ${ }^{*} p<0.05, * * p<0.01$

TABLE 4. Factors associated with AQP using multiple linear regression

\begin{tabular}{|c|c|c|c|}
\hline Associated factors & $\mathrm{B}$ & SE & p-value \\
\hline Number of respiratory symptoms & 0.752 & 0.242 & $0.002 * *$ \\
\hline Age (years) & -0.043 & 0.029 & 0.140 \\
\hline Income (baht/month) & 1.124 & 0.529 & $0.035^{*}$ \\
\hline Occupation & 0.764 & 0.927 & 0.410 \\
\hline Smoking & 2.604 & 1.092 & $0.018 *$ \\
\hline Distance from home to stone factories (meters) & -0.022 & 0.011 & $0.044^{*}$ \\
\hline
\end{tabular}

${ }^{*} p<0.05, * * p<0.01$

the air pollution sources have a higher level of air quality perception than those living in other conditions, and that the residents in the neighborhood of air pollution sources have greater awareness about health risks from the familiar environmental hazards (Egondi et al. 2013; Li et al. 2016; Omanga et al. 2014; Pattinson et al. 2015). In Thailand people in communities having high risk of exposure to environmental pollutants appeared to have a high degree of health risks perception. This positive association between environmental pollution exposure risk and health risks perception is statistically significant (Janmaimool et al. 2014).

The strength of this study was that a geographic information system device was used to locate the position of stone factories and those residents living close to home stone factories for investigating the association between distance from air pollution sources and the air quality perception of residents living near stone factories. One limitation of this study was using a cross-sectional study which does not permit a clear explanation regarding the causal relationship between independent and dependent variables.

\section{CONCLUSION}

All home stone factories produce inhalable dust pollutants, especially $\mathrm{PM}_{10}$ containing crystalline silica, which affects respiratory symptoms and a poorer $\mathrm{AQP}$ of those residents living close to home stone factories. Periodically monitoring dust pollutant exposure, AQP and surveillance of respiratory illness should be performed. In addition, those residents living close to stone factories and stone operation workers should consider appropriate personal protective equipment. N95 masks should be recommended and support regarding a self-preventive measure for residents who living near the home stone factory during the time of production. Meanwhile, knowledge and advice should be provided to those residents living close to home stone factories, particularly lung disease patients, elderly and stone operation workers with respiratory symptoms who are more likely to receive adverse effects directly from air pollution for them to minimize the potential harm from continued exposure to air pollution from stone factories.

\section{ACKNOWLEDGEMENTS}

The authors would like to thank the subjects who participated in this study. This study was supported through funding by the Faculty of Medicine, Chiang Mai University, Thailand, Grant No. 129/2559 and 026/2560. The authors would also like to thank the Faculty of Medicine, Chiang Mai University for arranging for a professional English proofreader to edit the manuscript.

\section{REFERENCES}

Bhagia, L.J. 2012. Non-occupational exposure to silica dust. Indian Journal of Occupational and Environmental Medicine 16(3): 95-100. 
Brender, J.D., Maantay, J.A. \& Chakraborty, J. 2011. Residential proximity to environmental hazards and adverse health outcomes. American Journal of Public Health 101(1): S37-S52.

Brody, S.D., Peck, B.M. \& Highfield, W.E. 2004. Examining localized patterns of air quality perception in Texas: A spatial and statistical analysis. Risk Analysis 24(6): 15611574.

Cassee, F.R., Héroux, M.E., Gerlofs-Nijland, M.E. \& Kelly, F.J. 2013. Particulate matter beyond mass: Recent health evidence on the role of fractions, chemical constituents and sources of emission. Inhalation Toxicology 25(14): 802812.

Charles, E., Thomas, D.S., Dewey, D., Davey, M., Ngallaba, S.E. \& Konje, E. 2013. A cross-sectional survey on knowledge and perceptions of health risks associated with arsenic and mercury contamination from artisanal gold mining in Tanzania. BMC Public Health 13: 74.

Crowe, M.J. 1968. Toward a 'definitional model' of public perceptions of air pollution. Journal of Air Pollution Control Association 18(3): 154-157.

Deguen, S., Pédrono, G., Segala, C. \& Mesbah, M. 2008. Association between pollution and public perception of Air Quality-SEQAP, a risk perception study in France. Epidemiology 19(6): S216.

Deguen, S., Petit, C., Delbarre, A., Kihal, W., Padilla, C., Benmarhnia, T., Lapostolle, A., Chauvin, P. \& ZmirouNavier, D. 2015. Neighbourhood characteristics and longterm air pollution levels modify the association between the short-term nitrogen dioxide concentrations and all-cause mortality in Paris. PloS ONE 10(7): e0131463.

Deguen, S., Ségala, C., Pédrono, G. \& Mesbah, M. 2012. A new air quality perception scale for global assessment of air pollution health effects. Risk Analysis 32(12): 2043-2054.

Doungrutai, B. 1999. Effect of respirable particulates on lung function among traffic policemen in Bangkok. Thesis in Environmental Science. Thailand: Graduate School, Chulalongkron University (Unpublished).

Egondi, T., Kyobutungi, C., Ng, N., Muindi, K., Oti, S., Vijver, S.V.D. \& Rocklöv, J. 2013. Community perceptions of air pollution and related health risks in Nairobi Slums. International Journal of Environmental Research and Public Health 10(10): 4851-4868.

Guo, Y., Liu, F., Lu, Y., Mao, Z., Lu, H., Wu, Y., Chu, Y., Yu, L., Liu, Y., Ren, M., Li, N., Chen, X. \& Xiang, H. 2016. Factors affecting parent's perception on air qualityfrom the individual to the community level. International Journal of Environmental Research and Public Health 13(5): 493.

Haas, E.J., Willmer, D. \& Cecala, A.B. 2016. Formative research to reduce mine worker respirable silica dust exposure: A feasibility study to integrate technology into behavioral interventions. Pilot and Feasibility Studies 2: 6. doi: 10.1186/s40814-016-0047-1.

Healy, C.B., Coggins, M.A., Van Tongeren, M., MacCalman, L. \& McGowan, P. 2014. Determinants of respirable crystalline silica exposure among stoneworkers involved in stone restoration work. Annals Occupational Hygiene 58(1): 6-18

Helsing, K.J., Comstock, G.W., Speizer, F.E., Ferris, B.G., Lebowitz, M.D., Tockman, M.S. \& Burrows, B. 1979. Comparison of three standardized questionnaires on respiratory symptoms. American Review of Respiratory Disease 120(6): 1221-1231.
Ibhafidon, L.I., Obaseki, D.O., Erhabor, G.E., Akor, A.A., Irabor, I. \& Obioh, I.B. 2014. Respiratory symptoms, lung function and particulate matter pollution in residential indoor environment in Ile-Ife, Nigeria. Nigerian Medical Journal 55(1): 48-53.

Janmaimool, P. \& Watanabe, T. 2014. Evaluating determinants of environmental risk perception for risk management in contaminated sites. International Journal of Environmental Research and Public Health 11(6): 6291-6313.

Kuo, C.T., Chiu, F.F., Bao, B.Y. \& Chang, T.Y. 2018. Determination and prediction of respirable dust and crystalline-free silica in the Taiwanese Foundry industry. International Journal of Environmental Research and Public Health 15(10): E2105.

Liao, X., Tu, H., Maddock, J.E., Fan, S., Lan, G., Wu, Y., Yaun, Z.K. \& Lu, Y. 2015. Residents' perception of air quality, pollution sources, and air pollution control in Nanchang, China. Atmospheric Pollution Research 6(5): 835-841.

Li, Z., Folmer, H. \& Xue, J. 2016. Perception of air pollution in the Jinchuan mining area, China: A structural equation modeling approach. International Journal of Environmental Research and Public Health 13(7): 735.

Madungwe, E. \& Mukonzvi, T. 2012. Assessment of distribution and composition of quarry mine dust: Case of pomona stone quarries, Harare. Atmospheric and Climate Sciences 2: 5259.

Mannucci, P. \& Franchini, M. 2017. Health effects of ambient air pollution in developing countries. International Journal of Environmental Research and Public Health 14(9): E1048.

Mukhopadhyay, K., Ramalingam, A., Ramani, R., Dasu, V., Sadasivam, A., Kumar, P. \& Balakrishnan, K. 2011. Exposure to respirable particulates and silica in and around the stone crushing units in central India. Industrial Health 49(2): 221-227.

National Institute on Occupational Safety and Health (NIOSH). 2003. Silica, Crystalline, by VIS: Method 7601. Atlanta: NIOSH. https://www.cdc.gov/niosh/docs/2003-154/ pdfs/7601.pdf.

National Institute on Occupational Safety and Health (NIOSH). 1998. Particulates Not Otherwise Regulated, Respirable: Method 0600. Atlanta: NIOSH. https://www.cdc.gov/niosh/ docs/2003-154/pdfs/0600.pdf.

Ngamjarus, C. 2016. n4Studies: Sample size calculation for an epidemiological study on a smart device. Siriraj Medical Journal 68(3): 160-170.

Omanga, E., Ulmer, L., Berhane, Z. \& Gatari, M. 2014. Industrial air pollution in rural Kenya: Community awareness, risk perception and associations between risk variables. $B M C$ Public Health 14: 377.

Orru, K., Nordin, S., Harzia, H. \& Orru, H. 2018. The role of perceived air pollution and health risk perception in health symptoms and disease: A population-based study combined with modelled levels of $\mathrm{PM}_{10}$. International Archives of Occupational and Environmental Health 91(5): 581-589.

Pattinson, W., Longley, I. \& Kingham, S. 2015. Proximity to busy highways and local resident perceptions of air quality. Health \& Place 31: 154-162.

Piro, F.N., Madsen, C., Næss, Ø., Nafstad, P. \& Claussen, B. 2008. A comparison of self reported air pollution problems and GIS-modeled levels of air pollution in people with and without chronic diseases. BMC Environmental Health 7: 9.

Qian, X., Xu, G., Li, L., Shen, Y., He, T., Liang, Y., Yang, Z., Zhou, W.W. \& Xu, J. 2016. Knowledge and perceptions 
of air pollution in Ningbo, China. BMC Public Health 16: 1138.

Rafeemanesh, E., Majdi, M.R., Ehteshamfar, S.M., Fahoul, M.J. \& Sadeghian, Z. 2014. Respiratory diseases in agate grinding workers in Iran. International Journal of Occupational and Environmental Medicine 5(3): 130-136.

Scarselli, A., Binazzi, A., Forastiere, F., Cavariani, F. \& Marinaccio, A. 2011. Industry and job-specific mortality after occupational exposure to silica dust. Occupational Medicine (Lond) 61(6): 422-429.

Severtson, D.J. \& Burt, J.E. 2012. The influence of mapped hazards on risk beliefs: A proximity-based modeling approach. Risk Analysis 32(2): 259-280.

Shi, X. \& He, F. 2012. The environmental pollution perception of residents in coal mining areas: A case study in the Hancheng Mine Area, Shaanxi Province, China. Environmental Management 50(4): 505-513.

Thongtip, S., Siviroj, P., Deesomchok, A., Prapamontol, T., Wisetborisut, A. \& Khacha-Ananda, S. 2019. Effects of high silica exposure on respiratory disorders among stone-mortar workers in Northern Thailand. Southeast Asian Journal of Tropical Medicine and Public Health 50(2): 401-410.

Vacek, P.M., Verma, D.K., Graham, W.G., Callas, P.W. \& Gibbs, G.W. 2011. Mortality in Vermont granite workers and its association with silica exposure. Occupational and Environmental Medicine 68(5): 312-318.

\section{Sakesun Thongtip}

Division of Environmental Health

School of Medicine

University of Phayao

Phayao, 56000

Thailand
Athavudh Deesomchok

Department of Internal Medicine

Faculty of Medicine

Chiang Mai University

Chiang Mai, 50200

Thailand

Anawat Wisetborisut

Department of Family Medicine

Faculty of Medicine

Chiang Mai University

Chiang Mai, 50200

Thailand

Tippawan Prapamontol

Research Institute for Health Sciences

Chiang Mai University

Chiang Mai, 50200

Thailand

Penprapa Siviroj*

Department of Community Medicine

Faculty of Medicine

Chiang Mai University

Chiang Mai, 50200

Thailand

*Corresponding author; email: psiviroj@gmail.com

Received: 5 March 2019

Accepted: 6 December 2019 
